УДК 347.97/.99

DOI https://doi.org/10.32849/2663-5313/2020.6.43

\title{
Ірина Кондратова,
}

аспірант Академії адвокатури України

\section{ЕТИЧНА ОСНОВА СУДДІВСЬКОЇ ПРОФЕСІї}

Професійна діяльність судді є однією з небагатьох сфер державної діяльності, яка регулюється не лише нормами законодавчих актів, які зобов'язують суддю діяти на підставі та в межах законів, але й нормами моралі, що становлять етичну основу поведінки, забезпечуючи авторитет постаті судді у суспільстві. Причина такої «вибірковості» криється у спечифіиі суддівської професії, яка зорієнтована на постійну, необмежену комунікаиію з людьми. Це вимагає від судді не лише володіти певним набором чеснот, а й демонструвати, втілювати їх у своїй роботі та повсякденному житті. Люди, які за своїм професійним призначенням наділені інструментом впливати на людські долі, а подекуди «вирішувати» їx, повинні мати на ие не лише формальне, але й морально право.

На переконання автора, етична основа суддівської професії зумовлена низкою об'єктивних передумов, які пов'язані з особливостями діяльності судді, а також роллю, яку відведено судовій владі у суспільстві.

До них насамперед автор відносить спеиифіку судового прочесу, який від самого початку та до винесення рішення у справі пронизує ідея справедливості, що є однією з найважливіших категорій етики. Крім того, зазначається конфліктогенність судового процесу, що спонукає суддю бути бездоганним, не давати жодної можливості засумніватися в тому, що він заслужено є суб'єктом реалізації функиї правосуддя, якою наділила його держава.

Наступним чинником автор називає незалежність судді. На його думку, вона передбачає відповідний спосіб мислення судді, наявність у нъого установок і його особисте переконання в тому, що у своїй діяльності він може керуватися лише власним розумінням права та закону, уникаючи спокус і розглядаючи будь-який вплив (чи то дружне прохання, чи то владний тиск) на нвого як незаконний.

Окремо автор наголошує на корпоративності, яка вимагає від суддів поваги один до одного. Вони повинні усвідомлювати, що крізь призму поведінки одного судді у суспільстві формується уявлення про всю суддівську спільноту. Неприпустимим є вираз у будь-якій формі зневаги до колег чи до судової системи. Це підриває авторитет правосуддя в державі.

Ключові слова: суддівська етика, етика судді, професійна етика, поведінка судді, професія судді, статус судді.

Постановка проблеми. Сучасний стан реалізації в Україні функції правосуддя та законодавчі ініціативи, спрямовані на удосконалення організації та діяльності судової влади, загострили увагу суспільства до постаті судді. Крізь призму професійної діяльності та поведінки у повсякденному житті представників суддівського корпусу громадськість почала оцінювати ефективність наявних у державі механізмів захисту прав, свобод та інтересів особи, що має визначальне значення у формуванні суспільної довіри до судової влади.

Як наголошується у Висновку № 3 (2002) Консультативної ради європейських суддів до уваги Комітету міністрів Ради Свропи про принципи та правила, які регулюють професійну поведінку суддів, зокрема питання етики, несумісної поведінки та неупередженості, методи, які використовуються для вирішення спорів, мають завжди викликати довіру. Повноваження, що надані суддям, тісно пов'язанні 3 цінностями правосуддя, справедливості та свободи. Стандарти поведінки, які застосовуються до суддів, випливають із цих цінностей і $є$ передумовами довіри до правосуддя [1, с. 142].

Тож втілення міжнародних стандартів, еволюція поглядів на роль судової влади в державі, розвиток уявлень про справедливий суд і статус судді зумовили появу нормативних положень, відповідно до яких суддя зобов'язаний справедливо, безсторонньо та своєчасно розглядати судові справи; дотримуватися правил суддівської етики, зокрема, виявляти та підтримувати високі стандарти поведінки у будь-якій діяльності з метою укріплення суспільної довіри до суду, забезпечення впевненості суспільства в чесності та непідкупності суддів; виявляти повагу до учасників процесу тощо (ст. 56 Закону України «Про судоустрій і статус суддів).

Наведене свідчить, що сьогодні визначальну роль у суддівській професії відіграє етичний складник, дослідження якого має теоретичне та праксеологічне значення. 
Аналіз останніх досліджень i публікацій. Серед вітчизняних науковців до різних аспектів суддівської етики у своїх роботах зверталися В. В. Городовенко [2], Ю. А. Меліхова [3], Л. М. Москвич [4], О. М. Овчаренко [5], І. Л. Самсін [6], Л. В. Тацій [7], О. 3. Хотинська-Нор [8] та інші. Проте чимало питань, пов'язаних з етичною основою суддівської діяльності, залишаються мало дослідженими та потребують наукового аналізу.

Метою статті є визначення, науковий аналіз і характеристика окремих чинників, які зумовлюють етичну основу суддівської професії.

Виклад основного матеріалу. Слід розпочати 3 того, що професійна діяльність судді є однією з небагатьох сфер державної діяльності, яка регулюється не лише нормами законодавчих актів, які зобов'язують суддю діяти на підставі та в межах законів, але й нормами моралі, що становлять етичну основу поведінки, забезпечуючи авторитет постаті судді у суспільстві. Причина такої «вибірковості» криється у специфіці суддівської професії, яка зорієнтована на постійну, необмежену комунікацію з людьми, різноманіття статусів і поведінки яких вимагає від судді не лише володіти певним набором чеснот, а й демонструвати, втілювати їх у своїй роботі та повсякденному житті. Люди, які за своїм професійним призначенням наділенні інструментом впливати на людські долі, а подекуди «вирішувати» їх, повинні мати на це не лише формальне, але й морально право.

У цьому контексті взірцевими є слова сера Жерара Бреннана - Головного судді Австралії, який у своїй промові, звертаючись до учасників Національної програми суддівської орієнтації (Австралія, 13.10.1996р.), наголосив: «Роль судді полягає в тому, щоб служити суспільству у ключовій справі здійснення правосуддя відповідно до закону. Ваша посада дає вам таку можливість, і це - привілей. Ваша посада вимагає від вас служіння і це обов'язок. <..> Ваш привілей - виконувати свої обов'язки, і ваш обов'язок - залишити свою посаду незаплямованою, коли настане час скласти повноваження. Ваші слова та дії як у публічному просторі, так і певною мірою в особистому житті впливатимуть на суспільне ставлення до вашої посади і на повагу, яку ця посада мала б викликати. Ризик бути затриманим за кермом під час повернення додому з бенкету чи незначні погрішності у сумі доходу, вказані в податковій декларації, можуть мати суспільне значення. Стандарти дружини Цезаря - це ті стандарти, які інші справедливо застосовуватимуть до того, що ви кажете і робите, відтак, зважаючи на неймовірну велич вашої посади як судді, це стандарти, які ви застосовуватимете до себе. Ці стандарти стосуються як великих, так і малих справ. Часом використання підзвітних сум чи квитанція для підтвердження витрат може мати неабияке значення. Плічо-пліч із величчю, яка пов'язана з посадою, іде й скромність щодо власної здатності бути гідним стандартів, визначених попередниками, дотримання яких чекають від особи, яка обійняла посаду» [9].

Традиційно мораль розглядається як форма індивідуальної та суспільної свідомості. У свою чергу, філософська наука, яка вивчає мораль, отримала назву етика. Етика (лат. ethika, від грец. ethos - звичай) досліджує природу, сутність, виникнення, розвиток, структуру, функції моралі, її прояви у різноманітних сферах діяльності. Із розвитком етики як загальнофілософського вчення відбулося виокремлення її окремого розділу - етики професійної. Особливістю професійної етики є те, що вона концентрує в собі ті моральні норми та вимоги, що визначають відносини осіб певної професії, регулюючи при цьому духовно-моральні аспекти спілкування, що виникають у їх середовищі завдяки спільній діяльності. Професійна етика зумовлена особливостями окремих професій, корпоративними інтересами, професійною культурою. Люди, які виконують однакові чи схожі професійні функції, виробляють специфічні традиції, об’єднуються на основі професійної солідарності, підтримують репутацію своєї соціальної групи. Професійна етика - це сукупність правил поведінки певної соціальної групи, яка забезпечує моральний характер взаємовідносин, зумовлених чи пов'язаних із професійною діяльністю [10, с. 309-310].

Етична основа суддівської професії зумовлена низкою об'єктивних передумов, які пов'язані з особливостями діяльності судді, а також роллю, яку відведено судовій владі у суспільстві. Серед них, на нашу думку, насамперед варто виокремити такі:

1. Специфіка судового процесу, кінцевою метою якого є захист прав, свобод та інтересів людини.

Судовий процес $є$ формою реалізації правосуддя, що здійснюється виключно судом, законодавчо визначеним завданням якого є забезпечення кожному права на справедливий суд (ст. 2 Закону України «Про судоустрій і статус суддів). Власне справедливість, яку окремі науковці розглядають як основоположний принцип судової влади [2, с. 91], відзначається багатоманітністю змістового 
навантаження та сьогодні $\epsilon$ характерною рисою і судової процедури, і результату судової діяльності, і сподівань стосовно особи судді.

Попри існування філософського, соціального, нормативного підгрунтя категорії справедливості, вона насамперед $є$ однією 3 найважливіших категорій етики. Із давніх часів справедливість розглядалася як властивість, якість людини. Так, наприклад, Аристотель розглядав справедливість як етичну чесноту, але особливого роду: вона є «досконалою чеснотою», «найбільшою з чеснот». На його думку, оскільки справедливість закладена в сутності людини, то, рухома нею, вона дотримуватиметься тільки справедливого закону, а несправедливий - ігноруватиме [11].

Досліджуючи філософсько-правовий вимір справедливості, О. Б. Прокопонко зазначає, що справедливість споконвіку була мірою людських вчинків, «якщо в періоди античності і середньовіччя справедливість вважалася якістю особистості, то пізніше вона стає ознакою дій і процедур». У контексті двох вимірів соціального буття - персонального та інституційного - науковець виділяє і два поняття справедливості: а) справедливість як характерна риса особистості, що належить до чотирьох головних ознак людини поряд із розважливістю, мужністю та розумом (мудрістю); б) справедливість, що стосується соціальних інститутів, а також політична справедливість, що стосується права, держави і політики [12, с. 14, 63].

Тож ідея справедливості, яка пронизує судовий процес, передусім зумовлена відповідними моральними якостями, особистісними характеристиками та власними суб'єктивними установками судді.

Як слушно з цього приводу зауважуе Л. Тацій, «установлення справедливості $€$ надзвичайно складним завданням, тому до судді висуваються високі моральні вимоги, які не можна виміряти емпіричними показниками, наприклад чесність та порядність, наявність загостреного відчуття справедливості, здатності не осуджувати людину за скоєний проступок, співчуття і вміння допомогти їй виправитися, скрупульозність у вивченні обставин справи, здатність виходити із презумпції невинуватості й трактувати сумніви на користь обвинуваченого та інше» [7].

Але не лише ця особливість судового процесу вимагає від судді дотримання етики у своїй діяльності.

Зокрема, мета, на яку зорієнтований судовий процес, зумовлює конфліктогенність його середовища у більшості випадків. Робота судді безпосередньо спрямована на врегулювання конфлікту, який виникає між людьми або ж людиною та державою. Вирішуючи конфлікт, суддя стає його осередком, привертаючи увагу до своїх дій і рішень з боку учасників судового процесу, присутніх у залі судового засідання та й загалом усіх небайдужих. Тому у своїй поведінці він має бути бездоганним, не даючи жодної можливості засумніватися в тому, що заслужено є суб'єктом реалізації функції правосуддя, якою наділила його держава. Не лише норми закону визначають зміст прийнятого суддею рішення, а і його уявлення про такі дихотомії, як добро та зло, справедливість і несправедливість, мораль і аморальність. Недаремно положення всіх процесуальних кодексів передбачають норму, відповідно до якої суддя оцінює докази за своїм особистим переконанням, що слугує передумовою законності та обгрунтованості судового рішення.

2. Незалежність судді як неодмінний і безспірний атрибут судової діяльності.

Незалежність, як багатогранний феномен, має різні сенси. Проте насамперед вона передбачає спосіб мислення судді, наявність у нього установок і його особисте переконання в тому, що у своїй діяльності він може керуватися лише власним розумінням права та закону, уникаючи спокус і розглядаючи будь-який вплив (чи то дружнє прохання, чи то владний тиск) на нього як незаконний. Саме наявність у судді «внутрішнього стрижня» $€$ тією моральною гарантією, яка здатна забезпечити незалежність судді, його авторитет і довіру з боку суспільства. Незалежність є тією цінністю, яка повинна бути притаманна свідомості кожного судді. Вона також об'єднує суддівську спільноту, визначаючи основи взаємовідносин суддів у професійному колі. I зрештою, незалежність $є$ необхідною ознакою судової влади в державі, яка сповідує цінності демократії.

Декларуючи незалежність як загальновизнаний обов'язковий атрибут функціонування судової влади в державі, як неодмінну умову здійснення правосуддя, міжнародні інституції наголошують на їі особливій етичній цінності. Так, у Бангалорських принципах поведінки суддів першим серед етичних стандартів поведінки суддів, адресованих їм для використання незалежно від країни діяльності, вказано незалежність: «Незалежність судових органів є передумовою забезпечення правопорядку та основною гарантією справедливого вирішення справи в суді. Отже, суддя має відстоювати та втілювати в життя принцип незалежності судових органів в його індивідуальному та колективному аспектах» [13]. Розкрива- 
ючи зміст цього принципу, автори Коментарів до Бангалорських принципів поведінки суддів наголошують на дуалізмі суддівської незалежності: «незалежність суддів - це водночас і спосіб мислення, і набір інституційних та функціональних механізмів. Перше стосується фактичної незалежності судді; друге - визначення таких відносин між судовою системою та іншими суб'єктами, зокрема іншими гілками влади, які б гарантували реальність незалежності та її сприйняття» [14, с. 41]. Тлумачачи критерії його застосування із посиланням на відповідні джерела, вони зазначають існування певної моральної дилеми, яка полягає у такому: «Чи можна від суддів очікувати, з одного боку, щоб вони володіли такими якостями, як такт, скромність, рішучість, чутливість, здоровий глузд та інтелектуальна строгість, чи виховували їх у собі, а з іншого боку, не справляли враження байдужої, замкнутої, вузьколобої, обмеженої, похмурої чи гордовитої людини? Безумовно, одночасне виконання ролей зразкового та звичайного громадянина виглядає як неможлива паралельна дія. Поведінку, яка одним видається пристойною та ввічливою, інші вважатимуть зарозумілою та офіціозною. У свою чергу, те, що одні засуджуватимуть як негідну поведінку, яка свідчить про брак поваги до посади судді, інші радісно вітатимуть як вияв почуття гумору та здатності не сприймати себе надто серйозно зі сторони посадових осіб суду» [14, с. 49].

Незалежність, серед іншого, передбачає неупередженість з боку судді. Бути неупередженим означає бути вільним від будь-яких зв'язків, прихильності чи необ'єктивності, які впливають або можуть сприйматися як такі, що впливають на здатність судді здійснювати судочинство незалежно [15].

3. Корпоративність (професійна солідарність)

Усвідомлення кожним із представників суддівського корпусу своєї соціальної ролі, своєї приналежності до спільноти, яка репрезентує судову владу у суспільстві, об'єднує суддів і створює умови для формування корпоративних цінностей і традицій, що дозволяють ідентифікувати суддів серед представників інших юридичних професій, а також специфікують їх правила поведінки. Корпоративність у такому випадку позитивно позначається на розвитку внутрішніх зв'язків у судовій системі. Вона вимагає взаємоповаги суддів один до одного. Проте вона також формує нетерпимість до колег, поведінка яких $є$ негідною та порочить статус судді, що підриває авторитет судової влади у суспільстві.
Корпоративність у контексті суддівської етики вимагає від усіх представників суддівської спільноти дотримання етичних норм. Негідна, аморальна поведінка одного судді підриває репутацію усіх суддів у державі. Прискіплива увага суспільства до проблем судової влади в Україні, що значною мірою коригується 3МI, доволі часто загострюється саме у разі негідної поведінки суддів, що негативно позначається на сприйнятті загалом суддівської спільноти. Негативна інформація доволі легко та швидко поширюється в інформаційному просторі, внаслідок чого крізь призму поведінки однієї особи (іï помилки чи свідомого нехтування професійним статусом) формується думка про представників усієї професії та підривається іï суспільний авторитет.

Корпоративність також вимагає від представників суддівського корпусу не допускати зневажливого, образливого ставлення один до одного, не конфліктувати, виносячи на широкий загал особисту неприязнь чи суб'єктивне ставлення до колег, що порочитиме звання судді. Висловлюючи оцінку дій, рішень колег, судді повинні бути стриманими та коректними.

Питання функціонування системи правосуддя є питаннями, які викликають інтерес громадськості. Тому особи, які працюють у судовій сфері, передусім судді, з належною обачністю та стриманістю повинні реалізовувати їхнє право на свободу вираження поглядів у всіх випадках, в яких авторитет i неупередженість правосуддя можуть бути поставлені під сумнів. Неприйнятними та такими, що підривають авторитет правосуддя, є лайливі або образливі висловлювання суддів у соціальних мережах або на офіційних заходах (конференціях, круглих столах, заходах для преси тощо) стосовно їхніх колег чи системи правосуддя як такої [16].

\section{Висновки}

Підсумовуючи, слід зауважити, що наведені в межах цієї публікації передумови, які зумовлюють етичний складник професійної діяльності судді, не вичерпують себе. Проте вони яскраво демонструють специфіку етичної основи суддівської професії, яка, відображаючи норми суспільної моралі, «кристалізувала» та ідентифікувала морально-ціннісний елемент правового статусу судді.

\section{Список використаних джерел:}

1. Висновок № 3 (2002) Консультативної ради європейських суддів до уваги Комітету міністрів Ради Європи про принципи та правила, які регулюють професійну поведінку суддів, зокрема 
питання етики, несумісної поведінки та неупередженості. Документи Консультативної ради європейсъких суддів: офіц. вид. / упоряд. А.О. Кавакін. 2-ге вид., допов. Київ: Ін Юре, 2017. 816 с.

2. Городовенко В.В. Принципи судової влади : монографія. Харків : Право, 2012. 448 с.

3. Меліхова Ю.А. Морально-професійна культура судді: історія і сучасність : монографія. Харків : Право, 2015. 224 с.

4. Москвич Л.М. Організаційно-правові проблеми статусу суддів : дис. ... канд. юрид. наук: 12.00.10. Харків, 2003. 224 с.

5. Овчаренко О. М. Порушення етичних норм як підстава відповідальності судді. Теорія $і$ практика правознавства: електрон. наук. фах. вид. 2013. № 2(4). URL: http://nauka.jur-academy. kharkov.ua/download/el_zbirnik/2.2013/46.pdf. (дата звернення: 20.05.2020).

6. Самсін І.Л. Порушення правил етики судді як дисциплінарний проступок. Вісник Верховного Суду України. 2008. № 5. С. 35-38.

7. Тацій Л. Етика судді та особливості їі нормативної регламентації. Вісник Національної академї правових наук Украйни. 2014. № 1. С. 75-85.

8. Хотинська-Нор О.З. Деонтологічні засади взаємодії адвоката та суду в процесі здійснення судочинства. Науковий вісник УжНУ. Серія «Право». 2018. № 51. Том. 2. С. 161-164.

9. Gerard Brennan. The Role of the Judge Wollongong, Australia. 13 October 1996. URL: https://www.hcourt.gov.au/assets/publications/ speeches/former-justices/brennanj/brennanj_ wollong.htm (дата звернення: 20.05.2020).
10. Бірюкова А.М. Адвокатура України в умовах глобалізації : монографія. Київ : Алерта, 2018. $424 \mathrm{c}$.

11. Дзьобань О.П., Мануйлов С.М. Справедливість як правова цінність: концептуалізація феномену. Вісник Національного університету «Юридична академія імені Ярослава Мудрого». 2015. № 1. C. 102-113.

12. Прокопенко О.П. Право на справедливий суд: концептуальний аналіз і практика реалізації : монографія. Харків : Видавництво «ФІНН», 2011. 248 c.

13. Бангалорські принципи поведінки суддів: схвалені Резолюцією Економічної та Соціальної Ради ООН від 27.07.2006 р. № 2006/23. URL: https://zakon.rada.gov.ua/laws/show/995 j67 (дата звернення: 16.05.2020).

14. Коментарі щодо Бангалорських принципів поведінки суддів: Управління ООН з наркотиків та злочинності, вересень 2007 р. 199 с. URL: http://rsu.gov.ua/uploads/article/komentaribangalorski-9818bfbb11.pdf (дата звернення: 15.05.2020).

15. Висновок № 1 (2001) Консультативної ради європейських суддів до уваги Комітету міністрів Ради Європи про стандарти незалежності судової влади та незмінюваності суддів. URL: https://zakon.rada.gov.ua/laws/show/994 a52 (дата звернення: 15.05.2020).

16. Постанова Великої Палати Верховного Суду від 17 січня 2019 р. у справі № 11-1010can18. URL: http://reyestr.court.gov.ua/ Review/79472855 (дата звернення: 15.05.2020).

\section{Kondratova Iryna. Ethical basis of profession of a judge}

The professional activity of a judge is one of the few fields of state activity regulated not only by the legislative instruments binding a judge to act based on and within the laws, but also by the standards of morality that form the ethical basis of behaviour, ensuring the authority of a judge in the society. The reason for such a selective approach lies in the specificity of the profession of a judge that is focused on constant and unlimited communication with people. This requires a judge not only to possess a certain number of virtues, but also to demonstrate and embody them in his/her work and daily life. People who by their profession are endowed with the tool to influence and sometimes even determine the human fates should have not only a formal but also a moral right to do so.

According to the author, the ethical basis of the profession of a judge is attributable to a number of objective preconditions, associated with the peculiarities of the judge's activity, as well as the role assigned to the judiciary in the society.

The author states that they include, first of all, the specific nature of the trial, which from the very beginning and until judgment delivery in the case is permeated by the idea of justice, being one of the most important categories of ethics. In addition, the author specifies the conflictogenic nature of the trial, which encourages a judge to be impeccable, to avoid any possible doubt that he/she deserves to be the subject of implementation of the function of justice, entrusted upon him/her by the state.

The next factor specified by the author is independence of a judge. In his view, it presupposes the relevant mindset of a judge, availability of certain attitudes and personal conviction that in his/her activities he/she must be guided only by his/her own understanding of law and order, avoiding enticements and recognizing any influence (whether a friendly request or pressure on the part of authorities) on him/her as illegal.

The author puts special emphasis on corporatism, which requires judges to respect each other. They must understand that perception of he whole judicial community is formed through the prism of behaviour of one judge in the society. It is unacceptable to express any form of contempt for the colleagues or judiciary. This undermines the authority of justice in the state.

Key words: ethics for judges, judicial ethics, professional ethics, behavior of judges, profession of judge, judge status. 